\title{
Dampak Kebijakan Pemerintah Daerah dalam Pengelolaan PKL di Kota Jakarta, Bandung dan Surabaya
}

\author{
Impact of Local Goverment Policy in Management of Street Vendors \\ in Jakarta, Bandung and Surabaya Citiess
}

Murtanti J.R.1,2, Septyani Widyastuti²

Diterima: 1 Mei 2020

Disetujui: 15 September 2020

\begin{abstract}
Abstrak: Indonesia sebagai negara berkembang, mempunyai jumlah PKL yang cukup besar, sehingga keberadaan PKL membutuhkan perhatian khusus. Hal ini dikarenakan para PKL secara dominan menempati ruang-ruang publik kota. Pengelolaan PKL di kota-kota besar di Indonesia berlandaskan regulasi yang disusun oleh masing-masing pemerintah daerah, mengacu dan berpedoman pada regulasi yang lebih tinggi. Kebijakan masing-masing daerah mempunyai karakteristik dan keunikan yang berbeda-beda. Jakarta, Surabaya dan Bandung merupakan kota besar di Indonesia yang mempunyai permasalahan PKL sekaligus mempunyai kebijakan pengelolaan PKL. Dari ketiga kota besar ini, akan digali kelebihan dan kekurangan muatan kebijakan yang dilihat dari beberapa aspek. Studi perbandingan dilakukan dengan mencermati regulasi yang terkait PKL, diperkaya dengan hasil penggalian informasi dari berbagai penelitian dan media massa. Dari sisi kebijakan ketiga kota menunjukkan kepeduliannya dengan keberadaan regulasi terkait PKL. Bentuk penataan yang ditempuh adalah Relokasi dan Stabilisasi. Ketiga kota juga didukung oleh pihak swasta dalam upaya pengelolaan PKL. Kontribusi terhadap perekonomian wilayah dan peningkatan pendapatan PKL. Dampak positif pengelolaan sendiri mendorong efisiensi penggunaan ruang kota sehingga kota tampak rapi, indah dan tidak macet. Namun PKL masih bermunculan di ruang-ruang lama maupun zona terlarang. Jika lokasi penataan jauh dari keramaian maka dampak utamanya adalah penurunan pendapatan PKL.
\end{abstract}

\section{Kata Kunci: dampak, pengelolaan PKL, stabilisasi}

\begin{abstract}
As a developing country, Indonesia has a huge number of street vendors. Because of that, the existence of street vendors needs a special attention. This special attention is needed because streer vendors mostly occupy city's public spaces. Street vendor management in Indonesia's cities is based on the regulations that was made by each regional government which is pointing to Indonesia's higher level of regulation. Each regional regulation has their own unique characteristics. Jakarta, Bandung, and Surabaya are big cities that have street vendor problems that also have street vendor management regulations. From those three cities, the advantages and disadvantages of their regulation's contents will be revealed, enriched by information digging and research results. From the regulation side, those three cities showed their concern about regulations regarding street vendors. The forms of restructuring that has been done are relocation and
\end{abstract}

\footnotetext{
${ }^{1}$ Program Studi Perencanaan Wilayah dan Kota FT UNS

${ }^{2}$ Pusat Informasi dan Pembangunan Wilayah, PIPW LPPM UNS
} 
stabilization. Those three cities are also supported by private sector regarding street vendor management. Street vendor management has a vital contribution towards regional economical growth and street vendor's income growth. These positive impacts increases the efficiency of city space management, so the city itself will look tidy, beautiful, and not congested, but street vendors are still poppimg out in restricted areas and old spaces, if the new managed locations are far from the crowds, the impact will decrease street vendor's income

Keywords: impact, management of Street Vendors, stabilization

\section{PENDAHULUAN}

Keberadaan sektor informal yang sporadis dan terus meningkat masih menjadi permasalahan yang dihadapi oleh banyak kota di Indonesia. PKL sebagai salah satu subsektor dari sektor informal menjadi jalan keluar memperoleh pekerjaan yang paling mudah bagi mereka yang tidak terserap oleh sektor formal. Memasuki sektor informal tidak memerlukan modal besar, sehingga sektor ini mudah dimasuki, termasuk PKL.

Akan tetapi, keberadaan PKL seringkali menimbulkan permasalahan seperti kemacetan dan kekumuhan karena seringkali menempati ruang publik (Adedeji, Fadamiro, \& Adeoye, 2014; Kettles, 2007; Rahayu et al., 2013; Rukmana, 2016). Hal ini lah yang menjadi penyebab PKL dianggap sebagai out of place (Boonjubun, 2017; Yatmo, 2008), sedangkan oleh Lefebvre (1974) dikenal dengan istilah dissosiated elemen. PKL seringkali beraglomerasi pada tempat-tempat yang sering dikunjungi orang dalam jumlah besar yang dekat dengan pasar publik, terminal dan daerah komersil lain (McGee \& Yeung, 1977). Keberadaan PKL dibutuhkan oleh sektor formal bawah, sehingga PKL mempunyai peluang untuk berkembang. Untuk mencegah PKL semakin sporadis dan mengganggu, dibutuhkan upaya pengelolaan melalui intervensi kebijakan pemerintah yang mengatur karakteristik aktivitas dan karakteristik berlokasinya (Lefebvre, 1974; Rahayu, Buchori, \& Widjajanti, 2018).

Bentuk penataan seperti relokasi, formalisasi, revitalisasi dan stabilisasi dikenal di hampir semua kota yang melakukan pengelolaan PKL seperti Surakarta, Bandung, Jakarta, Surabaya maupun kota-kota lainnya (Ramadhan, 2015; Sarjono, 2005; Tualeka, 2013; Weny, 2014). Dukungan terhadap keberadaan PKL juga dilakukan oleh banyak kota, berupa pemberian sarana dagang, sarana pendukung dagang, pembinaan, dan juga modal. Namun dukungan secara keruangan dalam arti PKL diberikan tempat yang layak sesuai dengan karakteristik lokasi dan karakteristik aktivitasnya belum banyak dilakukan.

Karakteristik PKL itu antara lain membutuhkan lokasi yang dekat dengan aktivitas utama yang produktif, mudah dijangkau, dekat dengan rumahnya dan yang paling penting berada di ruang-ruang strategis kota dengan peluang intensitas pengunjung tinggi tanpa perlu membayar sewa mahal seperti halnya pedagang pasar karena modal mereka yang kecil. Oleh karena itu, diperlukan pengelolaan agar PKL mendapatkan haknya dan ruang publik dapat digunakan sebagaimana mestinya secara adil oleh masyarakat secara luas. Pengelolaan PKL ini tentunya tidak dilakukan secara sembarangan. Untuk meminimalisasi konflik dalam pengelolaan perlu diadakan pendekatan yang persuasif dengan mengetahui karakteristik mereka (Rahayu, 2016). Pengelolaan PKL antara satu daerah dengan daerah lain akan berbeda, tergantung dengan kebijakan pemerintah daerah masing-masing. Adanya perbedaan cara dan proses pengelolaan di setiap daerah sangat memungkinkan untuk memunculkan dampak yang berbeda pula baik terhadap PKL, pemerintah maupun masyarakat luas. Apalagi jika dikaitkan dengan kondisi keruangan/spasial suatu kawasan kota. 


\section{METODE}

Penelitian ini menggunakan metode deskriptif kualitatif melalui upaya mendiskripsikan dan menyusun interpretasi dari suatu data dan informasi (Sugiyono, 2011). Tujuan penelitian ini untuk menggali penataan PKL di beberapa kota besar di Indonesia beserta dampak yang ditimbulkan. Adapun daerah yang akan diperbandingkan adalah Jakarta, Bandung dan Surabaya, karena ketiganya mempunyai status yang setara yaitu ibukota Provinsi. Pengumpulan data dilakukan melalui studi pustaka dari berbagai macam sumber yaitu regulasi, media massa dan literatur. Untuk meningkatkan nilai keakuratan dilakukan trianggulasi dengan melakukan wawancara kepada key person dari OPD yang mengelola PKL.

\section{HASIL DAN PEMBAHASAN}

Keberadaan PKL merupakan permasalahan yang tak luput dari perhatian pemerintah Indonesia. Para PKL seringkali menempati ruang publik dalam menjajakan dagangannya, sehingga dapat mengganggu pengguna ruang publik yang lain serta menimbulkan permasalahan, seperti kemacetan lalu lintas, menimbulkan tumpukan sampah, kekumuhan dan mengurangi estetika kota (Bhowmik, 2007; Kettles, 2007). Hal ini tidak akan terjadi jika PKL ditata dan diberikan tempat yang sesuai dengan karakteristiknya (Kettles, 2007). Oleh karena itu, beberapa kota besar di Indonesia mengeluarkan kebijakan untuk mengelola keberadaan PKL.

Beberapa kota di Indonesia yang telah mengeluarkan peraturan tentang PKL antara lain Jakarta, Bandung, dan Surabaya. Pemilihan ketiga kota tersebut didasarkan atas persamaan status ketiga kota tersebut sebagai ibukota provinsi. Adapun aspek yang akan dibahas dalam menghadapi permasalahan PKL di ketiga kota tersebut terkait regulasi yang menjadi dasar hukum keberadaan PKL, bentuk penataan yang dipilih, keterlibatan pihak ketiga, kontribusi langsung maupun tidak langsung dari penataan, dampak keruangan dan non keruangan dari penataan.

\section{a. Regulasi yang mendasari penataan PKL}

Beberapa tujuan dari penataan PKL adalah menjamin adanya dukungan ruang kepada PKL, membina dan menata PKL agar lebih tertib, rapi dan meningkatkan kualitas PKL itu sendiri, termasuk meningkatkan kesejahteraan PKL (Areeza, 2016; Rahayu, 2016). Salah satu cara untuk mewujudkan tujuan tersebut adalah dengan mengeluarkan peraturan yang mendukung upaya pengelolaan PKL. Kota Jakarta, Bandung maupun Surabaya, ketiganya memiliki peraturan yang mengatur tentang PKL, mulai dari penataan hingga pemberdayaan.

Tabel 1. Regulasi terkait Pengelolaan PKL di Tiga Kota Besar di Indonesia

\begin{tabular}{cl}
\hline Kota & \multicolumn{1}{c}{ Peraturan } \\
\hline Jakarta & - Perda No 1 Tahun 2012 tentang Rencana Tata Ruang Wilayah Jakarta 2030 berisi \\
& tentang pengembangan dan pemeliharaan kawasan pusat PKL dan Usaha Kecil \\
& Menengah serta penyediaan ruang bagi sektor informal di area pusat perniagaan dan \\
& perkantoran \\
& - Pergub DKI Jakarta No 33 Tahun 2010 tentang Pengaturan Tempat dan Pembinaan \\
& Usaha Mikro PKL di prov DKI Jakarta \\
& - Pergub DKI Jakarta No 10 Tahun 2015 tentang Penataan dan Permberdayaan PKL \\
Bandung & Perda No 18 Tahun 2011 tentang RTRW Kota Bandung Tentang Perwujudan ruang \\
& sektor informal berada di kawasan perdagangan dan jasa \\
& - Perda No 4 Tahun 2011 tentang Penataan dan Pembinaan Pedagang Kaki Lima. \\
\hline
\end{tabular}




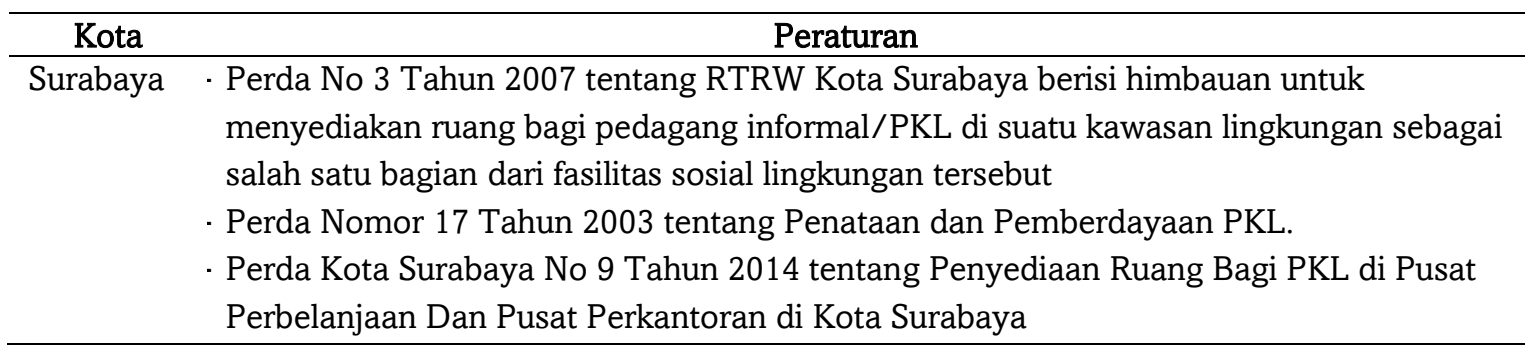

Kebijakan pengelolaan PKL yang berisi penataan serta pemberdayaan PKL juga dilakukan untuk mendukung pertumbuhan perekonomian bagi PKL sendiri serta bagi kota. Hal tersebut dapat terlihat dari penataan PKL yang dilakukan oleh Pemerintah Kota Surabaya, dimana melalui penataan PKL dapat memberi kontribusi terhadap peningkatan pendapatan daerah yang bersumber dari penarikan retribusi. Kota Jakarta, Surabaya dan Bandung memiliki kebijakan daerah yang sinergis antara dokumen rencana spasial/komprehensif dengan dokumen sektoral, mulai dari RTRW sampai dengan Perda khusus yang mengatur tentang PKL. Hal yang diamanahkan dari ketiga dokumen RTRW adalah adanya alokasi peruntukan ruang bagi sektor informal khususnya PKL. Di Jakarta peruntukan ruang bagi PKL adalah di pusat perniagaan dan perkantoran. Di Kota Surabaya peruntukan ruang bagi PKL berada di suatu kawasan lingkungan, sedangkan di Bandung peruntukan lahan bagi PKL berada di kawasan perdagangan dan jasa.

Dari ketiga RTRW tersebut terlihat bahwa peruntukan ruang bagi PKL di Jakarta dan Bandung berada di kawasan yang produktif, sehingga hal ini sesuai dengan karakteristik PKL. Namun RTRW Kota Surabaya tidak demikian. Di regulasi terkait tata ruang ini, hanya mengarahkan penataan PKL di kawasan lingkungan saja. Kawasan ini biasanya berdekatan dengan kawasan permukiman, yang potensi pengunjungnya tidak sebanyak jika berada di kawasan perdagangan dan jasa meski aktivitasnya lebih beragam. Hal ini dapat dimaknai bahwa penataan PKL kecil kemungkinan akan dilakukan di kawasan yang berdekatan dengan pusat aktivitas perdagangan, perkantoran dan jasa.

Kawasan-kawasan yang dapat menjadi peruntukan bagi penataan PKL di Kota Bandung dan Jakarta adalah kawasan perdagangan, perniagaan, perkantoran dan jasa. Kawasan-kawasan tersebut merupakan lokasi yang seringkali dikunjungi oleh banyak orang atau memiliki pergerakan tinggi, sehingga hal tersebut tentunya akan menguntungkan bagi PKL. Peruntukan lahan bagi PKL di lokasi yang tinggi pergerakannya juga sesuai dengan pernyataan McGee \& Yeung (1977) bahwa PKL seringkali beraglomerasi pada tempattempat yang sering dikunjungi orang dalam jumlah besar yang dekat dengan pasar publik, terminal dan daerah komersil lain. Pengelolaan PKL di Kota Bandung dan Jakarta lebih akomodatif terhadap karakteristik PKL tersebut.

Adapun untuk regulasi daerah yang mengatur tentang PKL di Kota Jakarta dan Surabaya memiliki kemiripan yaitu tidak hanya mengatur tentang lokasi penataan PKL tetapi juga pemberdayaan yang harus diberikan untuk PKL. Kebijakan pemberdayaan PKL di kedua kota tersebut juga memuat aspek yang hampir sama yaitu dengan memberi bantuan modal (dana, sarana dagang dsb.) serta peningkatan kualitas SDM PKL melalui pembinaan dan bimbingan teknis. Untuk regulasi PKL Kota Bandung sendiri belum disinggung tentang pemberdayaan PKL. Regulasi PKL Kota Bandung hanya menyebutkan salah satu hak PKL selain penataan adalah pembinaan. Pemberdayaan mempunyai lingkup yang lebih luas daripada pembinaan.

Terdapat hal yang menarik tentang kebijakan penataan PKL di Bandung, yaitu adanya pembagian zona lokasi PKL menjadi 3 zona yaitu merah, kuning dan hijau. Zona merah adalah lokasi yang terlarang bagi PKL, zona kuning adalah lokasi yang bersyarat bagi PKL dengan cara buka dan tutup operasionalnya berdasarkan waktu dan tempat yang 
telah ditentukan pemerintah. Adapun zona hijau adalah lokasi yang diperbolehkan bagi PKL. Masih banyaknya PKL yang menempati area-area terlarang setelah ditata juga merupakan dampak dari kurangnya pembinaan PKL. Menurut (Pamungkas, 2016), rendahnya jumlah PKL yang pernah mengikuti pembinaan, memiliki korelasi sangat kuat terhadap rendahnya pemahaman para PKL tentang penggunaan ruang publik yang dimanfaatkan untuk usaha. Meski penggunaan ruang publik seperti trotoar tidak terlarang untuk PKL (Kompas, 2018), namun harus dipahami adanya hak publik bagi semua masyarakat dalam menggunakan ruang publik tersebut, sehingga tidak terjadi hak menguasai oleh sebagian masyarakat, sehingga ruang publik dapat dimanfaatkan secara bersama dengan seimbang antara satu pengguna dengan pengguna lainnya (Lynch, 1987).

\section{b. Bentuk Penataan PKL}

Menurut McGee \& Yeung (1977), bentuk pengelolaan PKL dibedakan menjadi tiga, antara lain tindakan lokasional, tindakan struktural dan tindakan pendidikan. Dari tindakan lokasional, bentuk penataan yang dilakukan terkait dengan dukungan ruang bagi keberadaan PKL. Di tiga kota mempunyai bentuk penataan yang hampir sama yaitu relokasi dan stabilisasi. Relokasi adalah konsep penataan yang merupakan pemindahan PKL karena area yang mereka tempati sebelumnya sedang dibangun untuk kepentingan yang lain. Relokasi juga dikenal dengan istilah formalisasi, baik ke pasar tradisional maupun masuk ke toko modern (Sarjono, 2005).

Tabel 2. Bentuk Penataan PKL yang Dilakukan di Tiga Kota Besar di Indonesia

\begin{tabular}{|c|c|}
\hline Kota & Peraturan \\
\hline Jakarta & $\begin{array}{l}\text { - Relokasi (pemindahan pada lokasi baru ke zona-zona diperbolehkan } \\
\text { berjualan) dan penetapan zona berdagang/stabilisasi }\end{array}$ \\
\hline Bandung & $\begin{array}{l}\text { - Relokasi dari zona merah (terlarang) ke zona kuning dan zona hijau } \\
\text { (diperbolehkan) dan stabilisasi }\end{array}$ \\
\hline Surabaya & - Relokasi dan stabilisasi PKL ke dalam kios/shelter \\
\hline
\end{tabular}

Sumber: Weny (2014), Ramadhan (2015), Tualeka (2013).

Stabilisasi adalah bentuk penataan fisik atau penempatan PKL pada lokasi tertentu. Lokasi stabilisasi biasanya mengambil lokasi ruang publik yang tidak jauh dari lokasi lama (McGee \& Yeung, 1977; Rahayu, Putri, \& Rini, 2018). Meski menempati lahan yang sah, karena telah mendapatkan ijin penempatan, status PKL masih tergolong informal (Kettles, 2007; Puspitasari, 2010; Tualeka, 2013). Berikut adalah proses yang dilakukan oleh masingmasing kota dalam menata PKL.

Tabel 3. Proses yang Dilakukan dalam Pengelolaan PKL di Tiga Kota Besar di Indonesia

\begin{tabular}{lcc}
\hline \multicolumn{1}{c}{ Jakarta } & \multicolumn{1}{c}{ Bandung } & Surabaya \\
\hline $\begin{array}{l}\text { 1. Pendataan, untuk } \\
\text { mengetahui jumlah }\end{array}$ & 1. Pencatatan dan penertiban Tanda & 1.Pendataan PKL di lokasi \\
keseluruhan PKL & Pengenal khusus bagi PKL. Bagi PKL & PKL, terutama untuk PKL \\
yang akan ditertibkan & tidak boleh berjualan & yang ber KTP Surabaya \\
2. Penetapan lokasi & 2. Penataan PKL dengan system zonasi & daftar sentra yang akan \\
berjualan PKL, & - Zona merah adalah lokasi yang tidak & dibangun di suatu lokasi \\
dilakukan dengan & boleh terdapat PKL (sekitar tempat & tertentu \\
penzonaan lahan & ibadah, rumah sakit, komplek militer, & - Sampai tahun 2015 \\
yang boleh & jalan nasional, jalan provinsi dan & terdapat 42 sentra PKL \\
digunakan untuk & tempat lain berdasarkan Peraturan & yang tersebar di \\
berjualan bagi PKL & Perundang-undangan & seluruh wilayah \\
\hline
\end{tabular}




\begin{tabular}{|c|c|c|}
\hline Jakarta & Bandung & Surabaya \\
\hline $\begin{array}{l}\text { 3. Relokasi, PKL yang } \\
\text { sudah didata dan } \\
\text { berjualan dilokasi } \\
\text { terlarang akan } \\
\text { dipindahkan ke lokasi } \\
\text { baru sesuai } \\
\text { ketetapan } \\
\text { pemerintah } \\
\text { 4. Peremajaan dan } \\
\text { pembangunan } \\
\text { fasilitas pada lokasi } \\
\text { berjualan yang baru } \\
\text { 5. Pengawasan pasca } \\
\text { relokasi. Dilakukan } \\
\text { pemantauan pada } \\
\text { lokasi eks relokasi. } \\
\text { Bertujuan untuk } \\
\text { menyegerakan } \\
\text { adanya tindakan jika } \\
\text { ada pedagang yang } \\
\text { berjualan di lokasi } \\
\text { lama. }\end{array}$ & $\begin{array}{l}\text { - Zona kuning adalah lokasi yang bisa } \\
\text { tutup buka berdasarkan waktu dan } \\
\text { tempat (kantor Pemda yang tidak } \\
\text { digunakan, depan mall, sekitar } \\
\text { lapangan olahraga yang telah } \\
\text { ditetapkan sesuai ketentuan peraturan } \\
\text { perundang-undangan) } \\
\text { - Zona Hijau adalah lokasi yang } \\
\text { diperbolehkan berdagang bersama } \\
\text { (wilayah tempat relokasi, revitalisasi } \\
\text { pasar, konsep belanja tematik, konsep } \\
\text { festival dan konsep Pujasera sesuai } \\
\text { ketentuan berlaku) } \\
\text { 3. Memilih allternatif penertiban PKL, } \\
\text { antara lain } \\
\text { - Relokasi, dilakukan bila tidak tersedia } \\
\text { lahan dilokasi dan jumlah PKL terlalu } \\
\text { banyak } \\
\text { - Shelter Knok Down, jika dilokasi } \\
\text { masih tersedia lahan. Dilakukan } \\
\text { dengan pembangunan shelter } \\
\text { - Tenda, untuk wilayah yang lahannya } \\
\text { masih tersedia dan PKL hanya boleh } \\
\text { berjualan pada malam hari } \\
\text { - Gerobak, untuk wilayah yang } \\
\text { lahannya tidak tersedia shelter dan } \\
\text { tenda, sehingga lebih mudah untuk } \\
\text { dipindahkan } \\
\text { - Penertiban menjadi langkah terakhir } \\
\text { jika PKL tetap tidak mau mengikuti } \\
\text { program penataan pemerintah. }\end{array}$ & $\begin{array}{l}\text { Surabaya (Areeza et al, } \\
\text { 2016) } \\
\text { - Dinas Koperasi dan } \\
\text { UMKM Surabaya } \\
\text { belum melakukan } \\
\text { pembagian waktu di } \\
\text { kios/lapak pada sentra } \\
\text { PKL, karena jumlah } \\
\text { PKL masih mampu } \\
\text { menampung jumlah } \\
\text { PKL. } \\
\text { - Di sentra ini juga } \\
\text { terdapat berbagai } \\
\text { fasilitas seperti TV, } \\
\text { panggung, } \\
\text { perlengkapan hiburan, } \\
\text { serta rombong bagi } \\
\text { yang diberi fasilitas } \\
\text { rombong. } \\
\text { 3.Perencanaan tentang } \\
\text { bentuk pembinaan } \\
\text { dimasing-masing sentra } \\
\text { 4.Perencanaan tentang } \\
\text { pembenahan masing- } \\
\text { masing sentra }\end{array}$ \\
\hline
\end{tabular}

Dalam proses pengelolaan PKL di ketiga kota memiliki metode yang hampir sama yaitu melalui pendekatan kepada PKL terlebih dahulu. Pendataan PKL sebelum dilakukan penataan, dilakukan di semua kota. Namun hanya Kota Surabaya yang secara tegas, memprioritaskan warga dengan tanda pengenal Surabaya. Kota Jakarta dan Bandung, agak terbuka dengan tidak menuntut PKL-nya harus bertanda pengenal kota setempat. Pendekatan pemerintah kepada PKL pada masing-masing kota pada awalnya dengan melakukan dialog secara persuasif dengan PKL. Akan tetapi, semakin lama penataan PKL menjurus ke represif (Mashudi, 2014). Kota Surabaya dalam mengelola PKL telah melakukan komunikasi dengan baik kepada para pedagang (Orwala, 2015). Adapun di Kota Bandung, pendekatan kepada PKL yang akan ditertibkan dilakukan melalui pendekatan kelompok maupun pendekatan personal. Pendekatan ini selanjutnya diteruskan dengan proses pendataan, melegalkan status PKL dan pemberian ijin penempatan usaha (Ramadhan, 2015). Hal ini seperti yang dilakukan di Kota Surakarta, status usaha yang legal namun tetap dengan kegiatan informal (Kettles, 2007; Puspitasari, 2010; Rahayu, 2016; Tualeka, 2013). 
Seperti yang telah diuraikan di atas, bentuk dukungan keruangan dari pemerintah untuk masing-masing wilayah, hampir sama yaitu melalui penyediaan lahan/lapak ataupun shelter serta sentra-sentra PKL di lahan-lahan milik pemerintah. Hal ini sesuai dengan pendapat Blackburn (2011), bahwa ketersediaan lahan milik pemerintah menjadi persyaratan penting dalam penataan PKL. Dari regulasi ketiga kota, tampak bahwa regulasi pemerintah Kota Bandung yang secara tegas menyampaikan tentang penyediaan lahan bagi PKL. Pemerintah Kota Bandung, hanya akan merelokasi PKL jika tidak tersedia lahan di tempat lama dan jumlah PKL terlalu banyak. Jika tersedia lahan, maka penataan PKL dilakukan dengan membangun shelter dan penggunaan gerobak jika di lokasi belum terbangun shelter. Penetapan lokasi berdagang dengan sistem zona juga menunjukkan ketegasan pemerintah dalam mengatur keberadaan PKL.

Selain penyediaan lokasi penataan PKL, dukungan lain secara non keruangan juga diberikan dengan memberikan berbagai fasilitas panggung dan TV yang mampu mendukung keberlangsungan PKL. Hal ini dapat dilihat pada beberapa sentra PKL di Kota Surabaya yang juga diberikan pembinaan cara berjualan, keamanan dan ketertiban di lokasi berdagang. Sedangkan Kota Bandung dan Jakarta tidak menyediakan fasilitas fasilitas tersebut, kecuali para PKL sendiri yang mengadakan. Pemerintah Kota Jakarta, melakukan penyeragaman tenda dan lapak PKL, sedangkan pemerintah Kota Bandung melakukan pembinaan dan dukungan pendanaan/permodalan bagi PKL.

Dalam memilih lokasi penataan, dari ketiga kota besar tersebut dilakukan secara top down, tidak ada proses musyawarah sebelum diputuskan lokasi yang dianggap sesuai. Hal ini sangat berbeda dengan yang terjadi di Kota Surakarta, dimana sebelum lokasi diputuskan, dilakukan musyawarah antara dinas terkait bersama paguyupan PKL (Rahayu et al., 2013).

\section{c. Keterlibatan Pihak Ketiga dalam Penataan PKL}

Dalam mengelola kota apalagi jika terkait dengan kondisi perekonomian masyarakat, dibutuhkan pengelolaan yang sinergis oleh seluruh stakeholders kota, dari pemerintah, masyarakat maupun pihak swasta (Rahayu, Putri, \& Andini, 2016).

Tabel 4. Peran Pihak Ketiga dalam Pengelolaan PKL di Tiga Kota Besar di Indonesia

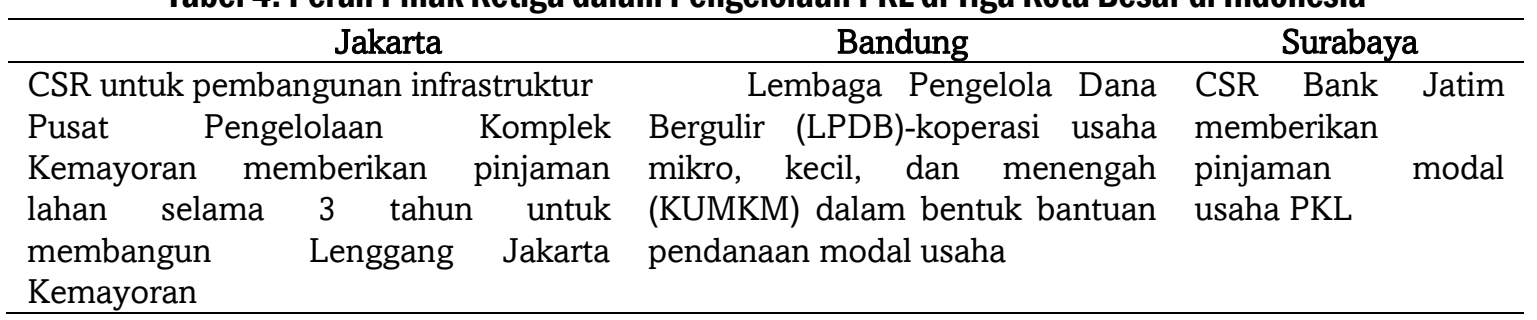

Sumber: Rahayu, Putri, \& Andini, 2016

Dalam upaya penertiban PKL di ketiga kota tersebut terdapat keterlibatan pihak ketiga untuk mendukung dalam beberapa aspek. Keterlibatan pihak ketiga pada penertiban PKL di Bandung dan Surabaya memiliki pola yang sama yaitu melalui pemberian modal usaha bagi PKL. Maksud dari pemberian modal usaha ini digunakan untuk menambah modal usaha bagi PKL, sehingga mampu meningkatkan kualitas maupun kuantitas dari usaha PKL. Menurut Tualeka (2013), pemberian dukungan berupa modal usaha adalah hal yang paling penting bagi PKL. Hal tersebut didasarkan pada argumen bahwa dengan pemberian modal dapat menjamin keberlangsungan penyediaan barang ataupun jasa PKL dan memperluas jaringan skala pelayanan. Pada akhirnya PKL akan mampu berkembang dan dapat maju menjadi wirausaha dengan status formal. Adapun untuk wilayah Jakarta memilki pola yang berbeda dibandingkan Bandung dan Surabaya. Keterlibatan pihak 
ketiga, lebih kepada dukungan pembangunan infrastruktur yang diperlukan oleh PKL seperti pembangunan Lenggang Jakarta Kemayoran oleh PPKK.

\section{d. Kontribusi Penataan PKL}

Penataan PKL dilakukan pemerintah bukannya tanpa tujuan dan harapan. Kontribusi atau manfaat secara luas yang diberikan PKL jika mereka ditata, menjadi salah satu dampak yang diinginkan dari penataan.

Tabel 5. Kontribusi Penataan PKL di Tiga Kota Besar di Indonesia

\begin{tabular}{|c|c|c|}
\hline Jakarta & Bandung & Surabaya \\
\hline $\begin{array}{l}\text { Peningkatan } \\
\text { regional/wilayah }\end{array}$ & $\begin{array}{l}\text { Kontribusi retribusi PKL dan potensi } \\
\text { meningkatnya kunjungan } \\
\text { pariwisata terhadap PAD }\end{array}$ & $\begin{array}{l}\text { Kontribusi retribusi } \\
\text { PKL }\end{array}$ \\
\hline $\begin{array}{l}\text { Peningkatan pendapatan } \\
\text { pedagang dan pelaku lainnya }\end{array}$ & $\begin{array}{l}\text { Menjadi sarana untuk menampilkan } \\
\text { produk unggulan Kota Bandung }\end{array}$ & $\begin{array}{l}\text { Alternatif wisata } \\
\text { kuliner baru di Kota } \\
\text { Surabaya }\end{array}$ \\
\hline
\end{tabular}

Pengelolaan PKL di ketiga kota tersebut ternyata memiliki kontribusi langsung yang sama yaitu adanya peningkatan pendapatan untuk daerahnya/PAD. Hal tersebut juga disampaikan oleh (Areeza, 2016), bahwa jika PKL dibina dan dikembangkan dengan baik, maka akan memiliki potensi yang cukup besar guna menambah pemasukan bagi PAD. Adapun selain menambah peningkatan PAD, peningkatan pendapatan dan kesejahteraan juga dapat dirasakan oleh PKL sendiri. Setelah menempati lahan yang tertata, dengan tetap menjadi pedagang informal, konsumen dapat lebih tertarik datang karena harga barang tetap murah, namun kondisi lokasi lebih baik dari sebelumnya. Hal ini akan meningkatkan omzet PKL yang berdampak pada penghasilan PKL yang meningkat. Pemberian modal usaha bagi PKL setelah mereka menempati lahan yang legal dengan surat ijin penempatan, dapat membantu PKL untuk menambah atau meningkatkan kualitas barang dagangannya. Untuk peningkatan PAD yang disumbang oleh sub sektor PKL dapat dilihat pada penerapan penataan PKL di Kota Surakarta. Selain Areeza (2016), penelitian yang dilakukan oleh Fatmawati (2013) menunjukkan bahwa penataan PKL yang dilakukan oleh Pemkot Surakarta memberi kontribusi terhadap peningkatan pendapatan yang tidak sedikit bagi pemerintah. Hal ini bisa dilihat dari jumlah Pendapatan Asli Daerah Kota Surakarta yang disumbangkan dari retribusi PKL pada tahun 2009 sebesar Rp. 234.452 .800 atau (4,5\%) dari total PAD Kota Surakarta sebesar Rp. 106.759.419.000 .

Selain kontribusi secara langsung, penataan PKL memiliki kontribusi secara tidak langsung, salah satunya sebagai daya tarik wisata. Hal ini dinyatakan secara jelas di regulasi Kota Bandung dan Kota Surabaya. Sentra-sentra PKL di dua kota ini diharapkan dapat menjadi magnet wisata. PKL yang ditata dengan baik, pada sentra-sentra ataupun lokasi Stabilisasi dan Relokasi, tentunya dapat menjadi lokasi tujuan wisata, sehingga hal tersebut dapat berdampak pada meningkatnya pemasukan PKL dan pemerintah. Selain itu, lokasi penataan PKL juga dapat menjadi landmark pada suatu kawasan.

\section{e. Dampak Penataan PKL}

Dampak penataan PKL ini dibedakan menjadi dampak keruangan dan dampak non keruangan. Dampak keruangan maupun non keruangan ini dapat menimbulkan dampak yang negatif maupun dampak positif. Hal-hal yang dapat dituliskan berikut ini terkait dengan kondisi yang tampak di masing-masing kota.

Ketiga kota ternyata merasakan dampak keruangan positif yang sama dengan adanya penataan PKL yaitu mengurangi kemacetan di jalan serta adanya efisiensi ruang serta memunculkan ruang kota yang lebih rapi, indah dan nyaman. Hal tersebut tentunya 
merupakan hal yang diharapkan dengan adanya penataan PKL, mengingat lokasi PKL sebelumnya berada di ruang-ruang publik seperti taman, trotoar dan dan pinggir jalan raya tanpa pengaturan, sehingga menganggu hak pejalan kaki, pengendara kendaraan bermotor dan juga pengguna taman. Keberadaan mereka di ruang publik, terutama di pinggir-pinggir jalan tentunya menjadi salah satu penyebab kemacetan yang sering terjadi di jalanan, karena daerah milik jalan yang berkurang.

Tabel 6. Dampak Penataan PKL

\begin{tabular}{|c|c|c|c|c|}
\hline \multicolumn{2}{|c|}{ Dampak } & Jakarta & Bandung & Surabaya \\
\hline Keruangan & Positif & $\begin{array}{l}\text { Efisiensi ruang dan } \\
\text { menanggulangi } \\
\text { kemacetan }\end{array}$ & $\begin{array}{lr}\text { Penataan } & \text { PKL } \\
\text { memunculkan } & \text { kesan } \\
\text { rapi dan tertib } & \end{array}$ & $\begin{array}{l}\text { Kondisi lingkungan } \\
\text { yang tertata dan lalu } \\
\text { lintas yang lebih tertib }\end{array}$ \\
\hline & Negative & 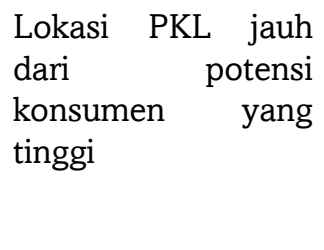 & $\begin{array}{l}\text { Munculnya PKL baru } \\
\text { di zona merah Kota } \\
\text { Bandung mengganggu } \\
\text { estetika dan } \\
\text { menimbulkan } \\
\text { kemacetan }\end{array}$ & - \\
\hline \multirow[t]{2}{*}{$\begin{array}{l}\text { Non } \\
\text { Keruangan }\end{array}$} & Positif & & $\begin{array}{l}\text { Daya tarik bagi } \\
\text { wisatawan dalam dan } \\
\text { luar negeri }\end{array}$ & $\begin{array}{l}\text { PKL mendukung } \\
\text { pengembangan } \\
\text { community-based- } \\
\text { tourism di Kota } \\
\text { Surabaya }\end{array}$ \\
\hline & Negative & $\begin{array}{l}\text { Lokasi relokasi yang } \\
\text { kurang sesuai } \\
\text { dengan karakteristik } \\
\text { PKL r sehingga } \\
\text { merugikan PKL }\end{array}$ & $\begin{array}{l}\text { Terjadi penurunan } \\
\text { pendapatan sebagian } \\
\text { PKL hasil penataan }\end{array}$ & - \\
\hline
\end{tabular}

Selain dampak keruangan yang positif, terdapat juga dampak keruangan negatif yang muncul di Kota Jakarta dan Bandung. Sebagian PKL di Kota Jakarta yang mengalami penataan merasakan bahwa lokasi mereka saat ini kurang mampu menarik konsumen datang, karena letaknya berada di dalam. Hal ini tidak sesuai dengan karakteristik lokasi PKL yang seharusnya dekat dan terlihat (Rahayu et al., 2016; Werdiningtyas, et al., 2012). Dampak negatif keruangan juga terjadi di Kota Bandung yaitu dengan munculnya kembali PKL di zona merah. PKL yang telah ditata dan dikeluarkan dari area ini kembali lagi ke area ini yang notabene adalah zona terlarang bagi PKL.

Setelah PKL dipindahkan dari lokasi lama ke lokasi baru, mereka merasakan pendapatan yang berkurang drastis dibanding sebelum ditata. Salah satu contohnya adalah PKL Tanah Abang yang pendapatannya berkurang ketika berjualan di lokasi baru. Hal tersebut dikarenakan pengunjung kesulitan mencari lapak tempat berjualannya sekarang karena tidak mudah dijangkau, tidak dekat dan tidak terlihat.

Hal yang berbeda terjadi di Kota Surabaya, dimana penataan PKL direncanakan sebagai upaya mendukung pengembangan community-based-tourism di Kota Surabaya. Pengelolaan PKL yang menekankan pada kearifan setempat akan menjadi ciri khas dan daya tarik wisata sekaligus mendorong pemberdayaan ekonomi lokal. Hal ini juga dilakukan di Kota Bandung dengan berbagai potensi kuliner dan fashion-nya.

Dari beberapa aspek yang terkait erat dengan upaya penataan PKL diatas, menunjukkan bahwa, secara umum, penataan PKL di Indonesia memilih bentuk stabilisasi, yaitu menata PKL di lokasi lama, atau di lokasi yang tidak jauh dari lokasi sebelumnya. Hal ini sesuai dengan pendapat Kettles (2007) dan Rahayu et al., 2013 . Bahwa PKL yang ditata ke dalam pasar, akan mendorong mereka keluar dari lokasi penataan dan kembali ke jalanan. 
Di sisi lain agar keberadaan PKL yang telah ditata mempunyai keberlanjutan, maka pengelolaan PKL harus mempertimbangkan karakteristik/potensinya dan menyesuaikan dengan konteks lingkungannya (McGee \& Yeung, 1977; Yatmo, 2008). Jika dikaitkan dengan pemahaman informalitas perkotaan, maka kota harus menempatkan PKL secara integral dalam sistem ekonomi perkotaan dengan memberikan sebagian ruang publiknya bagi PKL (Rukmana, 2005). Pengelolaan Stabilisasi PKL di kota-kota di Indonesai dapat menjadi bukti komitmen pemerintah yang akan mewujudkan place based economy. Hal ini sesuai pendapat Soetomo (2009) bahwa seharusnya pemerintah mengalokasikan PKL di dalam perencanaan kota secara konsisten.

\section{KESIMPULAN}

Semua pemerintah ingin agar kotanya tampak serasi dan harmonis tanpa menghilangkan hak warganya. Untuk itulah pemerintah melakukan pengelolaan dan penataan PKL sebagai upaya mewujudkan hal tersebut. Dari tiga kota besar yaitu Jakarta, Bandung dan Surabaya, dapat diketahui bahwa dalam menangani permasalahan PKL pemerintah daerah mengeluarkan kebijakan melalui peraturan yang terintegrasi mulai dari peraturan tata ruang sampai dengan peraturan yang sifatnya teknis/sektoral.

Dalam penertiban PKL Kota Jakarta, Surabaya dan Bandung memiliki metode yang sama yaitu dengan pendekatan terlebih dahulu kepada PKL. Penataan PKL di ketiga kota tersebut dilakukan dengan cara yang sama melalui Relokasi dan Stabilisasi ke area-area yang diperbolehkan untuk berjualan. Sementara peran pihak swasta ditunjukkan melalui pemberian modal dan bantuan infrastruktur. Melalui pengelolaan PKL ada peningkatan pendapatan bagi ketiga kota tersebut, melalui penarikan retribusi dan kunjungan wisatawan. Penataan PKL menimbulkan dampak positif dan negatif. Dampak positif penataan PKL adalah adanya efisiensi ruang, mengurangi kemacetan dan adanya kesan rapi pada lokasi penataan. Adapun dampak negatifnya antara lain berkurangnya pendapatan PKL akibat berpindah ke lokasi baru yang kurang strategis.

Dari tiga kota besar Jakarta, Bandung dan Surabaya, dapat dinilai bahwa kota Surabaya mempunyai komitmen tertinggi disusul Kota Bandung dan yang terakhir Kota Jakarta dalam menata PKL-nya.

\section{UCAPAN TERIMA KASIH}

Terima kasih kepada Program Studi Perencanaan Wilayah dan Kota (PWK) FT dan terkhusus teman-teman yang telah banyak berkontribusi: Dr. Rr Ratri Werdiningyas, ST,MT; Rufia Andisetyana Putri, ST,MT; Dr. Musyawaroh, MT atas dukungannya dalam proses penelitian dan penyusunan berbagai artikel publikasinya. Semoga penelitian ini bermanfaat bagi keilmuan dan masyarakat.

\section{DAFTAR PUSTAKA}

Adedeji, J. A., Fadamiro, J. A., \& Adeoye, A. O. (2014). Spatial Implications of Street Trading in Osogbo Traditional City Centre , Nigeria. Architecture Research, 4(1A), 34-44. https://doi.org/10.5923/s.arch.201401.05

Areeza, T. (2016). Evaluasi Kebijakan Penataan PKL di Sentra PKL Manukan Lor Kota Surabaya. Kajian Kebijakan Publik, 01(01).

Bhowmik, S. K. (2007). Street Vending in Urban India: The Struggle for Recognition. In 2Street Entrepreneurs People, Place, and Politics in Local and Global Perspective (hal. 114-129). New York.

Blackburn, S. (2011). Jakarta Sejarah 400 Tahun. Jakarta: Yayasan Bambu.

Boonjubun, C. (2017). Conflict over streets: The of Bangkok Street Vendors. Cities, 70, 22-31.

Fatmawati, N. (2013). Dampak Relokasi Pedagang Kaki Lima berdasarkan Peraturan Daerah Kota Surakarta nomor 3 Tahun 2008 tentang Pengelolaan Pedagang Kaki Lima terhadap Usaha Pedagang Kaki Lima di Kota Surakarta. Semarang: UNNES. 
Kettles, G. W. (2007). Legal Responses to Sidewalk Vending: The Case of Los Angeles, California. In Street Entrepreneurs People, Place, and Politics in Local and Global Perspective (hal. 58-78). New York: Bunga Rampai.

Kompas. (2018). PKL, Aset Triliunan Rupiah Yang Gagap Dikelola.

Lefebvre, H. (1974). The Production of Space. Oxford: Blackwell Publishers.

Lynch, K. (1987). A Theory of Good City Form. Cambridge Massachusetts: The MIT Press.

Mashudi. (2014). Strategi Penataan PKL di Jalan Dewi Sartika Kota Bogor. IPB.

McGee, T. G., \& Yeung, Y. (1977). Hawkers in Southeast Asian Cities: Planning for The Bazaar Economy. Ottawa: International Development Research Centre.

Orwala, A. G. (2015). Implementasi Kebijakan Perda Surabaya No 17 Tahun 2003 Dalam Mengelola Pedagang Kaki Lima Yang Berada di Wilayah Kecamatan Sukolilo. Surabaya.

Pamungkas, B. (2016). Pedagang Kaki Lima dan Pengembangan Kota Analisa Kebijakan dan Pengelolaan Pasar Malam PKL Kota Jakarta dan Kuala Lumpur. In In Prosiding Seminar Nasional INDOCOMPAC.

Puspitasari. (2010). Penataan PKL Kuliner untuk Mewujudkan Fungsi Tata ruang Kota di Ruang Kota di Kota Yogyakarta dan Kabupaten Sleman. Jurnal Mimbar Hukum, 22(3), 588-606.

Rahayu, M. J. (2016). Perubahan Kondisi PKL Pasca Penataan Stabilisasi dan Relokasi di Kota Surakarta. In Sustainable Architecture and Urbanism (hal. 43-59).

Rahayu, M. J., Buchori, I., \& Widjajanti, R. (2018). Study of locations'characteristics for stabilization of street vendors in Surakarta City. IOP Conference Series: Earth and Environmental Science, 106(1). https://doi.org/10.1088/1755-1315/106/1/012063

Rahayu, M. J., Putri, R. A., \& Andini, I. (2016). Pengembangan Konsep Stabilisasi PKL Berbasis Ekonomi Kerakyatan dalam Mendukung Surakarta sebagai Kota Wisata. Surakarta: Universitas Sebelas Maret.

Rahayu, M. J., Putri, R. A., \& Rini, E. F. (2018). Sustainable Street Vendors Spatial Zoning Models in Surakarta. IOP Conference Series: Earth and Environmental Science, 123(1). https://doi.org/10.1088/1755$1315 / 123 / 1 / 012044$

Rahayu, M. J., Werdiningtyas, R., \& Musyawaroh. (2013). Stabilisasi Sebagai Bentuk Penataan PKL Makanan Siap Saji di Kota Surakarta. Jurnal Tata Loka, 15(1), 39-52.

Ramadhan, A. (2015). Implementasi Model Zonasi Penataan Pedagang Kaki Lima di Kota Bandung. Jurnal Pandacta, 10(1), 99-100.

Rukmana, D. (2005). Urbanisasi dan Perubahan Perilaku Penduduk. Jurnal Info URDI, 19.

Rukmana, D. (2016). Pedagang Kaki Lima dan Informalitas Perkotaan. Diambil dari http://www.uplink.or.id/content/view/212/68/lang,id/

Sarjono, Y. (2005). Pergulatan Pedagang Kaki Lima di Perkotaan. Surakarta: UMS Press.

Soetomo, S. (2009). Urbanisasi dan Morfologi Proses Perkembangan Peradaban\&Wadah Ruang Fisiknya: Menuju Ruang Kehidupan yang Manusiawi. Yogyakarta: Graha Ilmu.

Sugiyono. (2011). Metode Penelitian Kuantitatif, Kualitatif dan R\&D. Bandung: Alfabeta.

Tualeka, B. A. (2013). Memahami Kebijakan Pembinaan PKL Surabaya, Kajian Terhadap Perda Kota Surabaya No.17 Tahun 2003. DIA Jurnal Administrasi Publik, 11(1), 149-159.

Weny, I. (2014). Perbandingan Kebijakan dan Upaya Pemerintah Dalam Penertiban Pedagang Kaki Lima Antara Kabupaten Berau dengan Pasar Tanah Abang. eJuournal Ilmu Pemerintahan, 2(4), 3291-3295.

Werdiningtyas, R., Rahayu, M. J., \& Musyawaroh. (2012). Hawkers Behaviour and Characteristic As An Important Factor To Empower Local Economy. In 2nd CONVEEESH \& 13th SENVAR International Conference (hal. 1-9). Yogyakarta: Architecture Department DWCU.

Yatmo, Y. A. (2008). Street vendors as 'out of place'urban elements. Journal of Urban Design, 13(3), 387-402. https://doi.org/10.1080/13574800802320889 